\title{
Yeniden İşlevlendirme Kapsamında Tarihi Yapı Örneği; Kırşehir Cacabey Cami Analizi
}

\author{
Merve BAŞGÜL \\ Kırşehir Ahi Evran Üniversitesi \\ merve.basgul@ahievran.edu.tr \\ ORCID ID: 0000-0003-3821-2984 \\ Zeynep Yeşim İLERİSOY \\ Gazi Üniversitesi \\ zyharmankaya@gazi.edu.tr \\ ORCID ID: 0000-0003-1903-9119
}

\begin{tabular}{|c|c|c|}
\hline Araştırma Makalesi & & DOI: $10.31592 /$ aeusbed.803056 \\
\hline Geliş Tarihi: 30.09 .2020 & Revize Tarihi: 25.01 .2021 & Kabul Tarihi: 08.03.2021 \\
\hline
\end{tabular}

\section{Attf Bilgisi}

Başgül, M. ve İlerisoy, Z. Y. (2021). Yeniden işlevlendirme kapsamında tarihi yapı örneği; Kırşehir Cacabey Cami analizi. Ahi Evran Üniversitesi Sosyal Bilimler Enstitüsü Dergisi, 7(1), 163-182.

\section{$\ddot{0 z z}$}

Toplumun kültürünü yansıtan ve sahip olduğu değerleri ifade eden tarihi yapılar ait olduğu yılların önemli hazinelerindendir. İnşa edilmelerinden itibaren birçok farklı dış etkiye maruz kalan tarihi yapıların gelecek kuşaklara sağlıklı biçimde ulaştırılabilmeleri büyük önem arz etmektedir. Sürdürülebilirliklerini korumada yapının mevcut halinin, kullanıcı ihtiyaçlarına cevap verebilecek duruma gelebilmesi için farklı müdahaleler ile iyileştirmeler yapılmaktadır. Bu iyileştirmelerden birisi olan yeniden işlevlendirme, zaman içerisinde gelişen durumlara ve değişen şartlara bağlı olarak işlevini yitiren yapıların korunabilmesi adına tercih edilen yaygın bir uygulamadır. Fiziksel, mekânsal ve anlamsal dönüşümler içeren "yeniden işlevlendirme" kavramı eski işlevini kaybetmiş olan yapıya özgün işlevi dışında yeni bir kullanım alanı tanımlayan süreçtir. Bu çalışmada Anadolu'nun ilk rasathanesi olduğu düşünülen ve Kırşehir ili için bir sembol haline gelen Cacabey Medresesinin yeniden işlevlendirme süreci ele alınmıştır. Yapının tarihçesi hakkında bilgi verilmiş, mimari ve yapısal öğelerine değinilmiş, zaman içerisinde kazandığı işlevlerden ve geçirdiği onarımlardan bahsedilmiştir. Yapıldığı dönemin önemli bir ihtiyacını karşılayan ve eğitim amaçlı inşa edilen bu yapı, zamanla özgün işlevini yitirmiş ve günümüzde cami olarak kullanılmaya başlanmıştır. Cami işlevini kazanmasının bir sonucu olarak yapıda, ihtiyaca yönelik zorunlu mimari değişiklikler yaşanmış, bu değişikler ile yapı tekrar kullanıma açılmıştır. Kaybolan medrese işlevi ve yeniden tanımlanan cami işlevi sürecinde yapının kazandığı ya da kaybettiği mimari ve yapısal öğeler, plan ve kesit bazında incelenmiştir. Tanımlanan yeni işlevin yapının eski kimliğine, özgün mimarisine ve bulunduğu bölgeye uyumu; sosyo-kültürel, ekonomik ve fiziksel açıdan değerlendirilmiştir. Sonuç olarak yapının uzun yıllar korunabilmesinde restorasyon çalışmaları kadar yeniden işlevlendirilmesinin de önemli bir etkisi olduğuna ve tanımlanan cami işlevinin yapı ile en uyumlu işlev olduğuna karar verilmiş̧ir. Yeni işlev ile birlikte Cacabey Cami; kültürel turizme katkı sağladığı, sosyal açıdan insan ve çevre ile uyum yakaladığı, fiziksel olarak geri alınabilir müdahaleler içerdiği ve özgün halinin okunabilirliğini korunduğu için Kırşehir kentinde gurur duyulacak bir hazinedir.

Anahtar Kelimeler: Yeniden işlevlendirme, yapı-işlev uyumu, Cacabey Medresesi, Kırşehir.

\section{Architectural Analysis of Kursehir Cacabey Madrasah, Historical Building Example within the Scope of Re-functioning}

\begin{abstract}
Historical buildings that reflect the culture of the society are among important treasures of years to which they belong. Improvements are made with different interventions in order to ensure that the current state of the building can meet the needs of user in maintaining its sustainability. Re-functioning, one of these improvements, is a common practice that is preferred in order to protect the structures that have lost their function due to the developing conditions and changing conditions. In this study, re-functioning process of Cacabey Madrasah, which is thought to be first observatory of Anatolia and became symbol for Kırşehir province, is discussed. Information was given about history of the building, its architectural and structural elements, the functions it gained over time and the repairs it underwent were mentioned. As a result of gaining function of mosque, architectural changes took place in the building, and the building was opened to use again. The architectural and structural elements that the building gained or lost during the process of the madrasah function and redefined mosque function were examined on the basis of plan and section. The harmony of the defined new function with the old identity, original architecture and the region where it is located It has been evaluated in socio-cultural, economic and physical terms. As a result, it was decided that re-functioning of the building has an important effect on the preservation of the building for many years as well as restoration works and that the function of mosque described is the most compatible function with the building. Building with new
\end{abstract}


functionality; It is treasure to be proud of in city of Kırşehir, as it contributes to cultural tourism, adapts socially with people and environment, physically includes reversible interventions, and preserves its original readability.

Keywords; Re-functioning, structure-function harmony, Cacabey Madrasah, Kırşehir

\section{Giriş}

Kültürümüzün önemli bir parçası olan tarihi yapılar; gelişen ve değişen toplum koşulları, artan popülasyon ve toplumlar arası etkileşimler sonucunda eski önemini yitirmiştir. Bununla birlikte medrese yapılarına duyulan ihtiyaç ortadan kalkmaya başlamış ve 1924 yılında kabul edilen Tevhid-i Tedrisat kanunu ile eğitimde birliğe gidilerek medrese işlevine tamamen son verilmiştir. Bu durum birçok şehirde inşa edilmiş medrese yapılarını yok olma ihtimaliyle karşı karşıya bırakmıştır.

Yüzyıllar öncesinden günümüze kadar varlığını sürdürebilmiş medrese ve diğer tüm tarihi yapıların her toplum için değeri büyüktür. İnşa edildikleri dönemin nasıl kültürel değerlere sahip olduğu, ne gibi ekonomik ve sosyal şartlar altında hayat buldukları hakkında bilgi verirler. Geçmişimizle bağ kurabilmeye yardımcı olan bu yapılar geleceğe aktarılabilmeli ve sonraki nesillere bir belge niteliğinde sunulabilmelidir. $\mathrm{Bu}$ amaç doğrultusunda tarihi yapılar koruma altına alınmakta ve gerekli restorasyonlardan geçmektedirler. Fakat bu yapıları korumak için gereken müdahaleler sadece koruma ve restorasyondan ibaret olmamalıdır. Birçok tarihi yapı geçmişte kullanıldığı işlevini devam ettirebilirken medrese, kervansaray gibi yapılar günümüzde kendilerine yer bulamamaktadır. Bu tarz yapıların sürekliliğini sağlayabilmek adına onları restore ve muhafaza etmek yeterli olmayacaktır. Zira kullanılmayan, sadece bir süs gibi şehri bezeyen yapılar bir süre sonra hayattan kopmaya başlayacak ve atıl hale gelecektir. Böylesi bir sorunun önüne geçmek amacıyla günümüzde işlev sorunu yaşayan tarihi yapılar, yeni bir işlev ile tekrar hayata kazandırılmakta ve yapıların sürdürülebilirliği korunabilmektedir.

Yapılan çalışmada öncelikle tarihi yapılarda yeniden işlevlendirme hakkında bilgi verilmiş ve bu süreçte dikkat edilmesi gereken hususlar güncel alan yazın araştırması ile aktarılmıştır. Sonrasında tarihi yapılar, medrese özeline indirgenmiş ve bu kapsamda cami-medrese işlev uyumu değerlendirilmiştir. Türkiyeden seçilen farklı işlev ve nitelikteki medrese örnekleri ile konunun daha iyi anlaşılması amaçlanmıştır. Çalışmanın devamında odak olarak ele alınan Cacabey Medresesi'nin değişen koşullar neticesinde yeniden işlevlendirilmesi detaylandırılmış; yapının tarihçesinden, mimari ve yapısal özelliklerinden bahsedilmiş, zaman içerisinde kazandığ 1 işlevlere ve geçirdiği yenileme çalışmalarına değinilmiş̧ir. Son olarak ise özgün işlevi değiştirilmesi neticesinde maruz kaldığ1 müdahalelerin yapının eski kimliğine ve mimarisine uyumu, sosyo-kültürel, ekonomik ve fiziksel açıdan değerlendirilmiştir.

\section{Yöntem}

Bu başlık altında araştırmanın yöntemi hakkında açıklama yapılmaktadır. Açıklama; araştırma modeli, çalışma grubu, veri toplama araçları ve verilerin analizi başlıkları üzerine odaklanmaktadır.

\section{Araştırma Modeli}

Yapılan bu araştırmada varolan durumu nesnel bir şekilde ortaya koyabilmek, geçerli ve güvenilir yanıtlar bulabilmek amacıyla "Tarama Modeli” kullanılmıştır. Tarama, güncel durumu olduğu hali ile ortaya çıkarıp betimlemeye yarayan bir araştırma modelidir. Çalışma hakkında genel bir kanıya varılmasına ve değişkenler arasındaki ilişkinin tespit edilmesine yardımcı olur (Karasar, 2007). Tarama modeli hem nitel hem de nicel araştırma yöntemlerine sahiplik yapsa da bu çalışmada nitel yaklaşım yöntemi tercih edilmiştir.

\section{Çalışma Grubu}

Çalışma grubunu Kırşehir ili Merkez ilçesinde yer alan Anadolu Selçuklu dönemine ait Cacabey Medresesi oluşturmaktadır. Medresenin inşa edildiği yıllardan itibaren geçirdiği onarımlar ve kazandığı işlevler ise bu grubun alt birimleridir. 


\section{Veri Toplama Araçları}

Çalışmaya ait verilerin elde edilebilmesi için geniş çaplı alanyazın taraması yapılmıştır. Taramada ulusal ve uluslararası hakemli dergiler, lisansüstü tezler, raporlar ve çalışmaya yönelik kitaplar incelenmiştir. Gerekli resmi kaynaklara devlet arşivlerinden ulaşılmıştır. Yapıya ait rölöve çizimleri ve şimdiye kadar yapılmış olan restorasyon projeleri Kayseri Vakıflar Genel Müdürlüğü’nden, yapı hakkındaki resmi yazışmalar ise Türkiye Cumhuriyeti Cumhurbaşkanlığı Devlet Arşivleri Başkanlığı'nın sitesinden temin edilmiştir. Sonrasında yerinde alan çalışması yapılarak yapının mevcut hali gözlemlenmiş ve fotoğraflanmıştır.

\section{Verilerin Toplanması ve Analizi}

Yapılan çalışmada toplanan güncel ve geçmiş tarihli görsel ve yazılı verilerin dökümü yapılmıştır. Sonrasında elde edilen veriler betimsel analiz yöntemi ile çözümlenmiş̧ir. Bu yöntem dahilinde mevcut veriler paylaşılmış ve bu veriler üzerinden çıkarımlarda bulunulmuştur.

\section{Araştırma Etiği}

Yapılan çalışmada; anket, mülakat, gözlem, deney ve görüşme teknikleri gibi veri toplama yöntemleri kullanılmamış ayrıca insan veya hayvanların bilimsel amaçlar ile kullanıldığı çalışmalar yapılmamıştır. Bu sebeplerden ötürü hazırlanan bu makale için etik kurul kararı gerekli değildir.

\section{Bulgular}

\section{Tarihi Yapılarda Yeniden İşlevlendirme}

İlerleyen zaman içerisinde; çevresel, ekonomik, sosyal ve kültürel değişimlerden kaynaklı olarak kimi tarihi yapılar özgün işlevlerini devam ettiremez duruma gelmektedir. Bu tarz yapıların gerekli restorasyonlardan geçmesi ve koruma önlemlerinin alınması sürdürülebilirliklerini devam ettirmek adına tek başına yeterli bir çalışma değildir. Korunabilmeleri ve kullanımlarını sürdürebilmeleri için yeni bir işleve sahip olmaları gerekmektedir (İslamoğlu, 2018). Yeniden işlevlendirme, eski fonksiyonlarını kaybetmiş olan yapıya özgün işlevi dışında yeni bir kullanım alanı sağlayan süreçtir. Günümüz koruma anlayışında sıklıkla karşılaştı̆̆ımız bu yöntem, tarihi yapıların eski kimliklerini muhafaza ederken onlara yeni bir kimlik kazandırmakta ve uzun yıllar kullanımını sağlamaktadır.

İtalyan asıllı mimar Gustavo Giovannoni tarihi yapıların korunmas1 ve atıl hale gelmemesi konusunda ortak bir görüş savunmaktadır. Giovannoni'ye göre tarihi yapıların kimliğine ve mimari yapısına uygun yeni bir işlev tanımlanması gerekmektedir (Aydın ve Şahin, 2018). 1964 yılında yayımlanan Venedik Tüzüğü’nde de belirtildiğine göre tarihi yapıları korumak için onları kullanıma açmak önerilmektedir. Tüzügün özellikle 5. Maddesi yeniden işlevlendirmeden ve işlevlendirmenin sınırlarından bahsetmektedir. 1964 yılında yayımlanan Venedik Tüzüğü'nün 5. maddesi şu şekildedir:

“Anıtların korunması her zaman onları herhangi bir yararlı toplumsal amaç için kullanmakla kolaylaştırılabilir. Bunun için bu çeşit bir kullanım arzu edilir, fakat bu nedenle yapının planı, ya da süslemeleri değiştirilmemelidir. Ancak bu sınırlar içinde yeni işlevin gerektirdiği değişiklikler tasarlanabilir ve buna izin verilebilir."

1975 yılında yayımlanan Amsterdam Bildirisi de Venedik Tüzüğü’nü destekler niteliktedir. Bildiride tarihi yapılar için belirlenen yeni işlevin yapıya uyumlu olmasına, sosyal çevre düzenini bozmamasına ve yenileme çalışmalarının yapılması gerekliliğine dikkat çekilmiştir (Saraç ve Tanrısever, 2018). Tarihi yapılara kazandırılacak yeni işlev; sosyo-kültürel, ekonomik ve fiziksel açıdan sürdürülebilirliğin sağlanmasında önemli bir yer tutarken aynı zamanda bu yapılar için yeni bir yaşantı ve bunun beraberinde yeni anlamlar ortaya çıkarmaktadır (Özkan Yazgan, 2011). 
Tarihi yapının toplumla olan ilişkisi, ona kazandırılan işlev ile sağlanmaktadır. Yeniden kullanıma açılan yapının sahip olduğu niteliklerin topluma iyi bir şekilde yansıtılması koruma politikalarının en önemli görevlerinden birisidir. Koruma politikasının sağlanabilmesi de kültür varlığının öneminin bilinmesine ve bu önemin neden kaynaklı olduğunun bilinmesine bağlıdır (Worthing ve Bond, 2008).

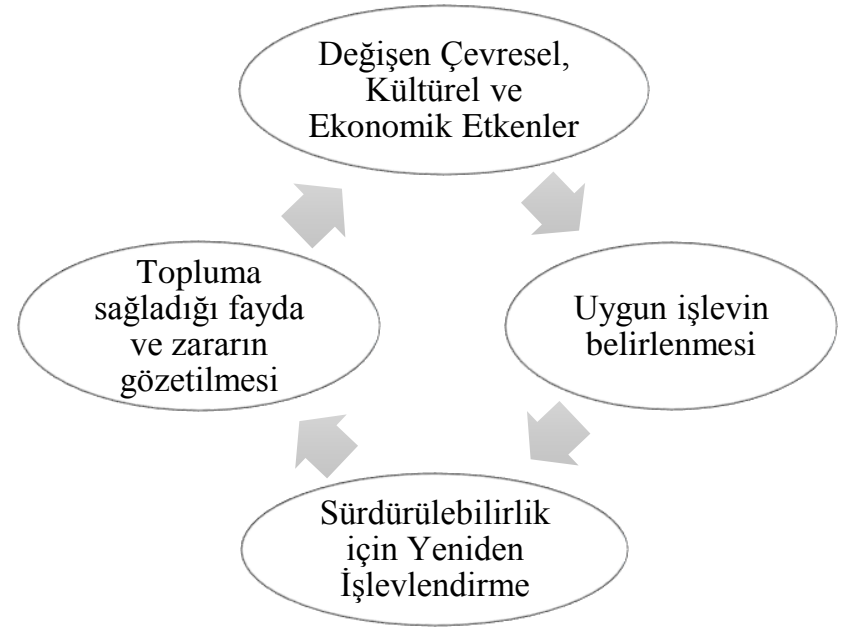

Şekil 1. Yeniden İşlevlendirilen Yapının Uyum Süreci

Şekil 1'de yeniden işlevlendirilen tarihi bir yapının sürdürülebilirlik süreçleri gösterilmiştir. Öncelikle değişen çevresel, kültürel ve ekonomik etmenler göz önünde bulundurularak yapıya uygun olan işlevin belirlenmesi gerekmektedir. Sonraki aşama da yapının sürdürülebilirliğini sağlamak amacı ile belirlenen işlev hayata geçirilmelidir. Uygulanan işlevin sağladığı yararlar ve zararlar gözetilerek sosyal, kültürel, fiziksel ve ekonomik açıdan değerlendirmesi yapılmalıdır. Elde edilen veriler neticesinde yeni işlevi ile uyum yakalayabilen yapının korunması devam ettirilirken uyum konusunda başarılı olamayan ve yapıya zarar veren işlev başta belirtilen etkenler neticesinde tekrar gözden geçirilmeli ve uygun bir fonksiyon ile süreç tekrarlanmalıdır. Sonuç olarak farklı bir işlevle yeniden kullanıma açılan yapı bulunduğu bölgeye ekonomik, kültürel ve sosyal açıdan katkı sağlarken aynı zamanda korunmuş olur ve varlığını devam ettirebilir.

\section{Yeniden İşlevlendirmede Dikkat Edilecek Hususlar}

Eski işlevini kaybetmiş yapılara kazandırılan yeni işlevlerde; yapının konumu, sahip olduğu plan tipi, kapladığı hacim, kazanacağı yeni işleve uyumu, özgünlügünün zarar görmemesi ve yeni işlevin yapının mimarisini, tarihini ve kültürel açıdan değerini zedeleyip zedelemeyeceği dikkate alınmalıdır. Yapının estetiğini değiştirecek uygulamalardan kaçınılmalı ve müdahaleler minimum düzeyde tutulmalıdır. Yapılacak değişiklikler geri alınabilir nitelikte olmalıdır. Yapının kazandığı yeni işlev ile uyumlu olması ve bu işleve cevap verebilecek özelliğe sahip olması önemli birer kriterdir (Aydın ve Şahin, 2018).

Maddeler halinde sırlaması aşağıdaki gibidir:

- Yapıya eski işlevi ve fiziksel özellikleri ile uyumlu olabilecek en makul işlev önerilmelidir (Kincaid, 2002).

- Yapının özgün planı yeni işleve cevap verebilmelidir (Gökçe, 2018).

- Yapılan değişiklikler geri döndürülebilir olmalıdır (Kincaid, 2002).

- Yapının orijinal boyutunda ve hacminde bir değişiklik yapılmamalıdır.

- Güncel malzemelerden kaçınılmalı eski muhafaza edilmelidir.

- Yapıya verilecek işlev, bulunduğu coğrafya ile uyum içinde olmalı ve insanların ihtiyaçlarını karşılayabilmelidir (Karapınar, 1997). 
- Yapıya bir müdahale yapılmak durumunda kalınırsa bu müdahale minimum düzeyde tutulmalıdır. Yapıya değer kaybettirecek bir müdahaleden kaçınılmalıdır (Yaldız, 2003).

- Yapısal elemanlara ve mimari öğelere zarar gelmeyecek şekilde işlev değişikliğine gidilmelidir (Yaldız, 2003).

\section{Medrese Genel Özellikleri}

Medrese; köken olarak ders fiilinden türemiş bir kelimedir. Derslerin anlatıldığı bina veya yüksekokul anlamı içermektedir. Medreseler, cami okullarından sonra ortaya çıkmışlardır (Kuran, 1969). 13. Yüzyıl itibari ile Anadolu sinırları içerisinde görülmeye başlanan Medrese yapıları plan geometrisi açısından kare veya kareye yakın dikdörtgen şemaya sahiptir. Kapalı veya açık avlulu, eyvanlı, tek veya iki katlı olarak inşa edilen medrese yapılarının plan şemasında dershane, hücre, revak, minare, kuyu/havuz ve türbe gibi öğeler de yer alabilmektedir (Kaya, 2018). Genel olarak incelendiğinde medrese yapılarının mimari elemanları avlu, dershane, hücre, eyvan, revak ve türbedir.

Avlu; tüm medrese yapılarında bulunan yapı elemanıdır. Medreseyi oluşturan birimler avlu çevresinde sıralanmaktadır. Ortak kullanım alanıdır. Eğitim alanı olarak da kullanılabilmektedir (Tekin, 2018). Kapalı avlulu ya da açık avlulu olmak üzere iki farklı plan tipinde gelişim göstermektedir. Açık avlulu plan tipinde üstü açık bir tasarım sergilenirken kapalı avlulu plan tipinde avlu, örtü elemanları ile geçilmektedir. Dershane ise mescit olarak da kullanılan, medresenin en büyük ve en önemli bölümüdür. Çoğu medresenin dershane bölümünde mihrap elemanı bulunur. Kapalı avlulu medreselerde her daim, açık avlulu medreselerde ise genellikle kışın kullanılan eğitim ve ibadet alanıdır. Kubbe ya da tonoz elemanlarla örtülü olarak karşımıza çıkmaktadır (Demiralp, 2006).

Medresede eğitim alan öğrencilerin konaklamaları ve çalışmaları için düzenlenmiş olan hücreler giriş veya ana eyvan aksına simetrik bir biçimde karşılıklı olarak sıralanmaktadırlar (Kuran, 1969). Hücreler doğrudan avluya ya da avluya açılan koridorlara açılırlar. Genellikle kubbe ya da tonoz elemanı ile örtülü bir çatıya sahiptirler. Hücre ölçüleri farklı boy ve yüksekliklerde olabilirler. Genelde küçük, kare ya da dikdörtgen plan şemasına sahiptirler. Mekanlar arasında sirkülasyonu sağlayan revaklar ise neredeyse tüm açı avlulu medreselerde görülmektedir. Ayaklar üzerinde taşınan üst örtü elemanları ile kapatılmış yarı açık mekanlardır (Tekin, 2018). Medreseye ait plan tipine göre değişkenlik gösterecek şekilde iki, üç veya dört cephede de revak elemanı olabilmektedir (Şak1, 2019). Eyvan elemanına baktığımızda üç tarafi kapalı, açık olan tarafı avluya bakan, avlu kotuna oranla belirli bir yükseklikte yer alan, üzeri kubbe veya tonoz elemanlar ile geçilmiş medrese elemanıdır (Yaldız, 2003). Avlu etrafında konumlanan, medrese öğrencilerine ders çalışma ve dinlenme alanı olarak tahsis edilen bölümdür. Medrese girişinin hemen karşısında yer alan ana eyvan çoğu medresede görülen bir yapı elemanı iken giriş eyvanı ve yan eyvanlar her medresede bulunmamaktadır (Demiralp, 2006). Türbe birimi ise medresenin inşasını gerçekleştiren kişinin mezarının bulunduğu medreseye bitişik ya da medrese içerisinde yer alan yapı elemanıdır. Bu birim yapıya sonradan eklenebileceği gibi yapı ile eşzamanlı da tasarlanabilmektedir (Yaldız, 2003). Genellikle medrese avlusunun yatay ve düşey akslarında yer alan eyvanların birinden girişi sağlanan, kare planlı üzeri kubbe elemanı ile geçilen mimari birimlerdir (Şaman Doğan, 2019).

\section{Cami - Medrese Yapılarının İşlev Uyumu ve Örnek İşlevlendirme Çalışmaları}

Medrese yapıları inşa edilmeden önce eğitim- öğretim çalışmaları camilerde ya da hocaların evlerinde yapılmaktaydı (Ahunbay, 1988). Artan nüfus, değişen sosyal ve kültürel çevre sonucunda camilerin yetersiz gelmeye başlaması medrese binalarına olan ihtiyacı ortaya çıkardı.

Camiler; ibadet görevinin yerine getirildiği mekanlar olmalarının dışında derslerin verildiği bir eğitim alanı olarak kullanıldığından bazı medreseler dershane birimine ilaveten bir cami ile birlikte tasarlanmıştır. Bazı medreselerde ise cami birimi ilave edilmeksizin medreseye ait dershane birimine mescit görevi de yüklenmiştir (Şimşek, 2017). En basit anlatımla cami ve medrese birimleri aslında her zaman iç içe tasarlanmışlardır. Birbirleri ile bağlantıları koparılmamaya gayret edilmiştir. 
Medrese yapıları kültürel, sosyal ve ekonomik nedenlerle değişen toplum karşısında önemini yitirmeye başlamış ve 1924 tarihli Tevhid-i Tedrisat kanunuyla özgün işlevini tamamen kaybetmiştir. Eski işlevinde kullanılamayan bu yapılara sonraki dönemlerde yeni işlevler uygun görülmüştür. Özellikle cami yapılarıyla olan ortak geçmişi ve yapıların işlev uyumu, medreseleri cami işlevinde kullanılmaya yöneltmiştir. Medreselerde en az müdahale ile en fazla uyum cami işlevinin verilmesi ile sağlanmıştır. Böylece iki farklı mimari eser, ortak bir noktada buluşabilmiştir.

Birçok medresede eğitim verilen bölüm olan dershane, medresenin aynı zamanda mescit görevi gören bölümüdür. Zamanında hem eğitim hem de ibadet amaçlı olarak kullanılan bu birim cami işlevi aldığında ibadet mekânı olarak cevap verebilmiştir. Ayrıca bu bölümde bulunan mihrap elemanı ve yapının kıbleye uygun olarak konumlanmış olması işlev değişikliğini destekler niteliktedir. Medresenin sahip olduğu geniş avlusu ve avlu etrafinda bulunan eyvan ya da revak birimleri cami işleviyle birlikte ibadet alanları olarak kullanılabilecek ferah alanlar oluşturabilmektedir. Yapının cephe boyunca dizili hücreleri de bayanlar için ibadet yeri, kütüphane ya da imam odası gibi farklı alanlara hizmet verebilecek niteliktedir. Kısacası cami ve medrese birbirinin yerine kullanılabilecek nitelikte bir plan yapısına ve işlev benzerliğine sahiptir.

Pearson ve Sullivan (2013), tarihi yapılarda yeniden kullanımı; en uygun işlevli yeniden kullanım ve uyumlu yeniden kullanım olmak üzere iki farklı yaklaşım üzerinden tartışmışlardır. En uygun işlevli yeniden kullanım uyumlu bir işlev kullanımının yanısıra yapının kültürel önemini de korurken uyumlu yeniden kullanım ise yapıya zarar vermeyen fakat kültürel önemini negatif etkileyen bir duruş sergilemektedir. Aradaki temel fark kültürel önemin korunması ve vurgulanmasıdır.

Türkiye'nin neredeyse tüm şehirlerinde halen varlığını sürdüren birçok medrese yapısı yer almaktadır. Bu yapılara geçen zaman içerisinde medrese işlevini kaybettiklerinden dolayı yeni bir işlev tanımlanmış ya da yapılar boş bırakılmışlardır. Tanımlanan kimi işlevler medrese yapılarına uygun düşerken bazı işlevler ise yapıyı kötü etkilemişlerdir. Türkiye'den seçilen medrese örnekleri ile tanımlanan farklı işlevlerin yapının özgün hali ile uyumu değerlendirilmiştir.

Kayseri Avgunu Medresesi (Fotoğraf 1 ve 2), günümüzde kitabevi olarak hizmet vermektedir. Yapının cephesi ile koruma duvarları arasında kalan kısım ise çay bahçesi olarak işlevlendirilmiştir (Kaya, 2018). Kitabevi işlevi, yapının eğitim kimliğine aykırı düşmemekle birlikte tam bir uyum sağlamamaktadır. Bununla birlikte çay bahçesi kimliği, yapıya birçok donatı elemanların eklenmesine sebep olmuştur. Sosya- kültürel açıdan ele alındığında yapının yeni işlevi kullanıcılar için yarar sağlarken bölge tanıtımına da yardımcı olmaktadır. Ayrıca yapının orijinal işlevi halen okunabilmektedir. Bununla birlikte kullanılan mazlemeler fiziksel açıdan geri alınabilir şekildedir. Yine de bu durum kullanılan malzemenin oluşturduğu görsel kirliliği görmezden gelmemize engel değildir. Ekonomik açıdan bakıldığında ise iki işlevi aynı anda bünyesinde barındırması yerel halka gelir kazandırırken aynı zamanda kültür turizmine de açıktır.

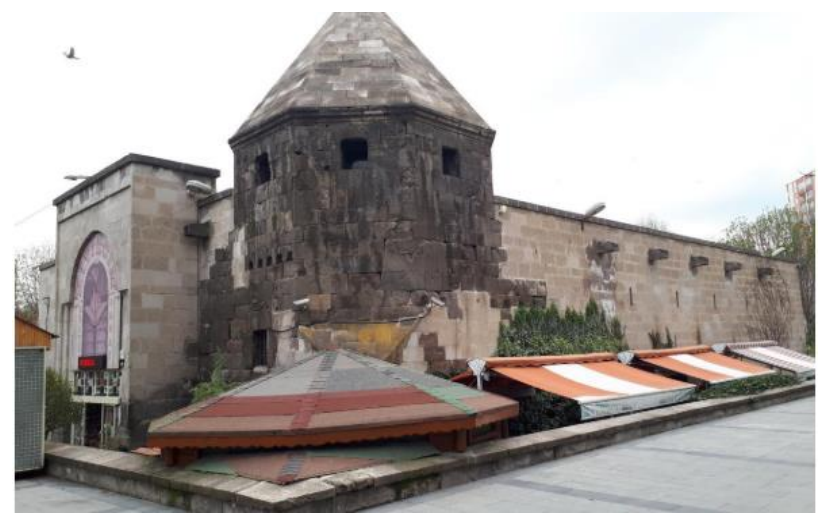

Fotoğraf 1. Kayseri Avgunu Medresesi Dış Mekân (Kaya, 2018). 


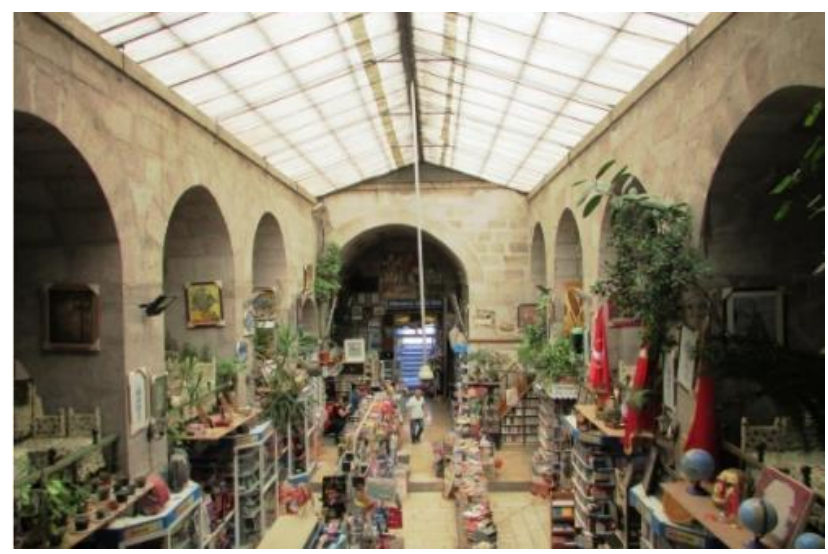

Fotoğraf 2. Kayseri Avgunu Medresesi İç Mekân (Kaya, 2018).

İstanbul'da yer alan Kara Ahmet Paşa Medresesi (Fotoğraf 3 ve 4), günümüzde Özel Gazi Ahmet Paşa Yüksek Öğrenim Öğrenci Yurdu olarak hizmet vermektedir. Yurt işlevi yapıya ağır gelmekte ve yapının birçok mimari ve yapısal öğesini olumsuz yönde etkilemektedir. Yapıya sonradan eklenen birtakım tesisatlar, aydınlatmalar ve bölücü duvarlar yapının orijinal işlevini zedelemektedir. Geri alınamaz malzemelerin varlığı yapıda ağır hasarlar meydana getirmektedir. Her ne kadar eski işlevi cephelerinden okunabilse de kazandığı yeni işlev birçok açıdan bu durumu gölgelemektedir. Ekonomik açıdan her kesime fayda sağlamaması ve kültür turizmine olan katkısını engellemesi, yeni işlevinin yapının orijinaline uymadığının göstergelerinden birkaçıdır.

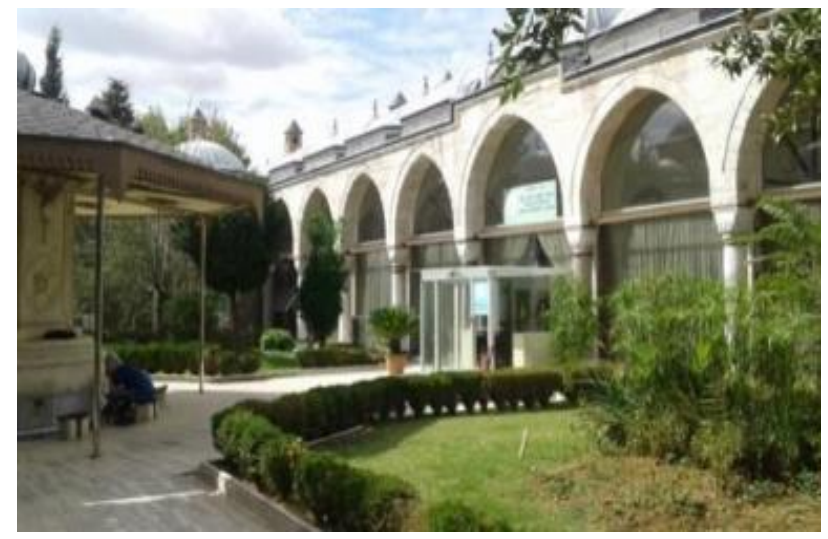

Fotoğraf 3. Kara Ahmet Paşa Medresesi Dış Mekân (Tekin, 2018)

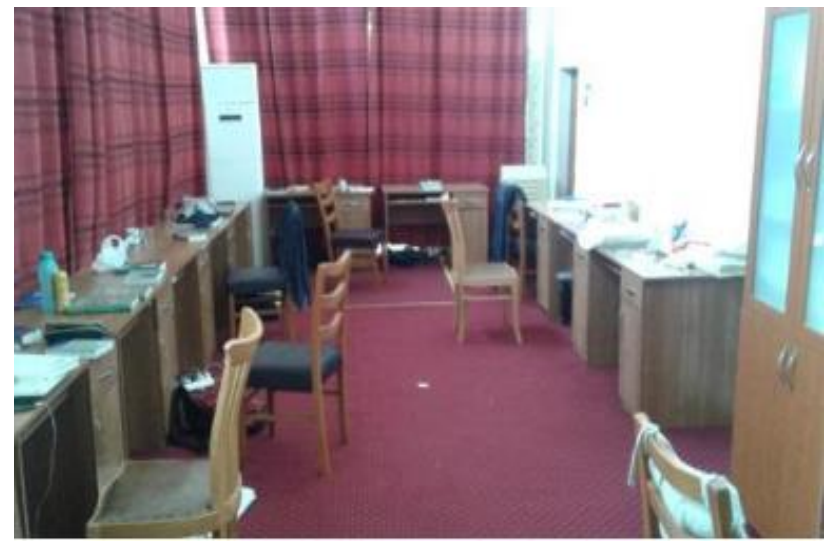

Fotoğraf 4. Kara Ahmet Paşa Medresesi İç Mekân (Tekin, 2018) 
Günümüzde kütüphane işlevinde kullanılan Şemsi Paşa Medresesi (Fotoğraf 5 ve 6) ise edindiği yeni işlevi ile uyum içerisindedir. Kazandığı yeni işlev eğitim yapısı kimliğine aykırı düşmemekte ve geçirdiği restorasyon ile özgün halini devam ettirebilmektedir (Öztürk ve Esmer, 2019). Sosyo-kültürel açıdan bölgenin eğitim seviyesini artırması ve yaşam koşullarını iyileştirmesi yeni işlevinin sağladığ1 artılardandır. Ayrıca kullanılan malzemelerin yapıya zarar vermeyecek nitelikte kullanılması, eski işlevinin halen farkedilebilir olması, görsel açıdan bir kirlilik oluşturmaması da yapının fiziksel açıdan yeni işlevi ile bir uyum içerisinde olduğunu sergilemektedir.

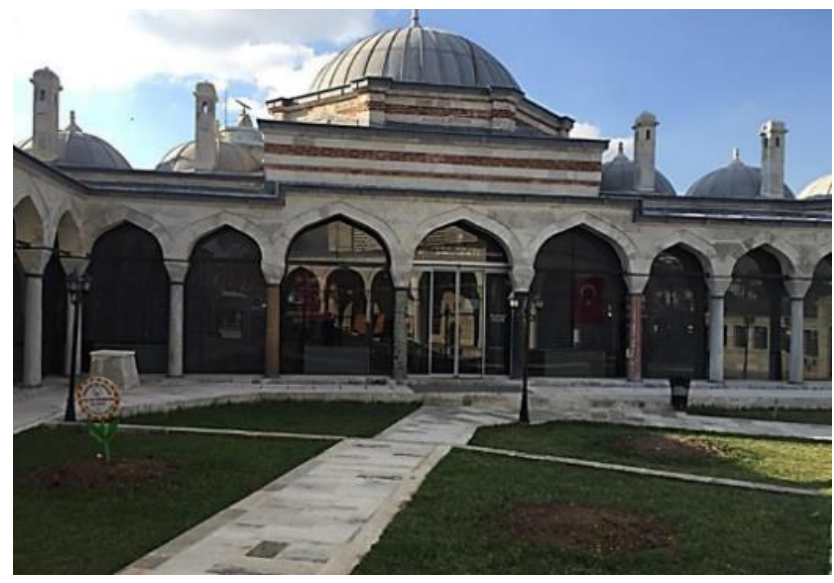

Fotoğraf 5. Şemsi Paşa Medresesi Diş Mekân (Öztürk ve Esmer, 2019)

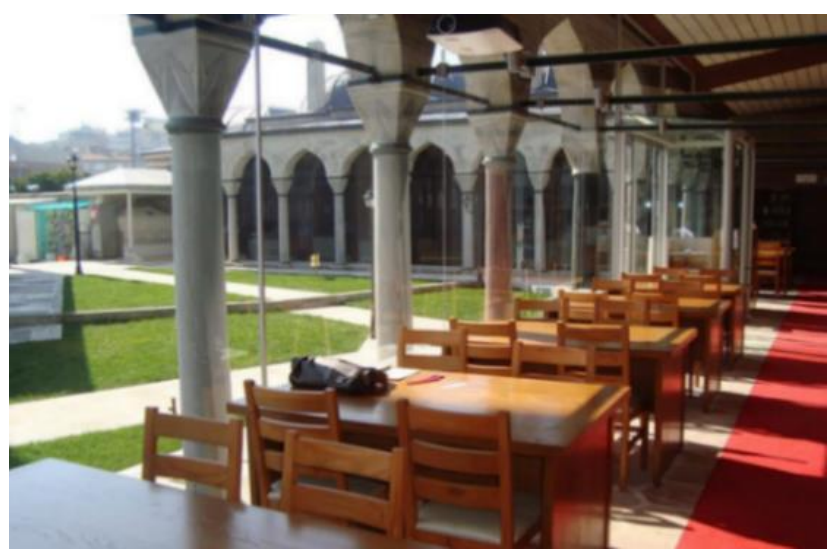

Fotoğraf 6. Şemsi Paşa Medresesi İç Mekân (Öztürk ve Esmer, 2019)

\section{Alan Çalışması: Cacabey Medresesi}

Kırşehir ili Merkez ilçesinde yer alan (Şekil 2), şehrin önemli yapılarının başında gelen ve günümüzde cami olarak kullanılan Cacabey Medresesi 1272-1273 yıllarında Anadolu Selçuklu zamanında dönemin Kırşehir valisi Nureddin Cibril Bin Caca tarafından yaptırılmışıtır. Mimarı belli değildir (Önkal, 1996). Medrese, plan şeması bakımından kapalı avlulu plan tipine güzel bir örnektir. Yapı, tamamen taş malzemeden inşa edilmiştir (Ünsal, Karaköse, Tuğluca, Özüçetin, 2013). İki katlı ve üç eyvanlı bir Anadolu Medresesi'dir. Yapıya giriş kuzey cephesinde bulunan Selçuklu motifleri ile bezenmiş, yapı kütlesine oranla daha yüksek ve görkemli olan taç kapıdan yapılmaktadır. Yapının kuzeydoğu köşesinde yaptıran kişiye ait kümbet elemanı yapıya bitişik halde bulunurken güneybatı köşesinde bulunan ve tuğla malzeme ile örülmüş minaresi ise yapıdan bağımsız halde bulunmaktadır. 


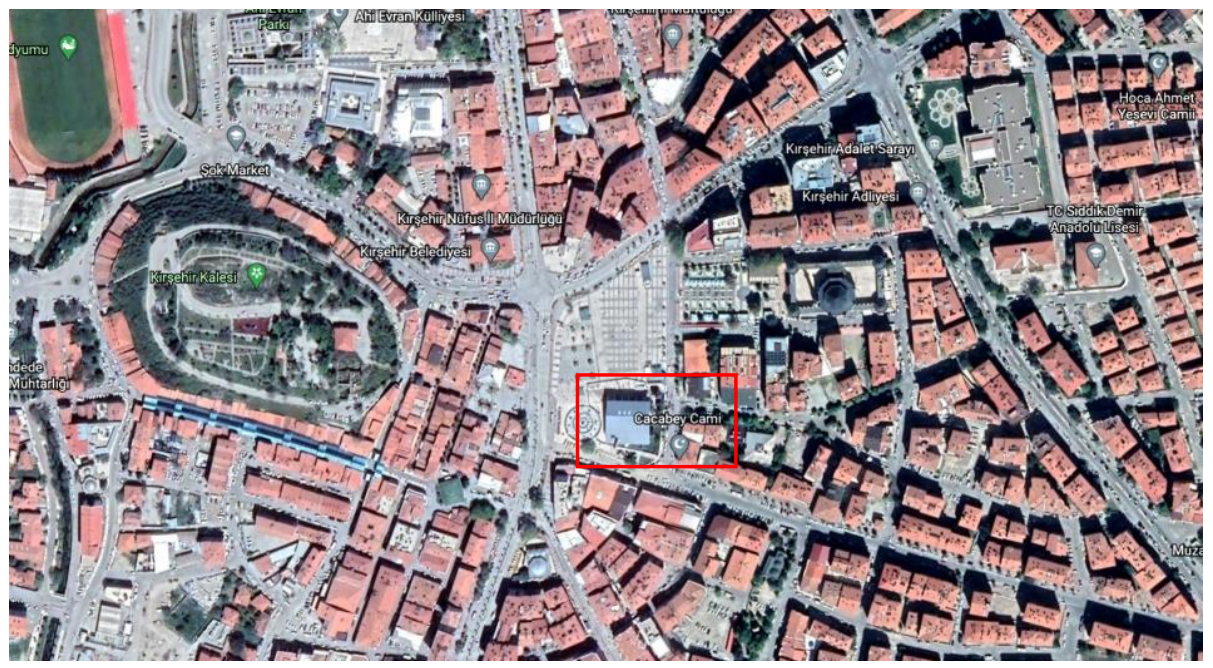

Şekil 2. Cacabey Medresesi Konumu ve Yakın Çevresi (https://earth.google.com/ adresinden 15.07.2020 tarihinde erişilmiştir.)

Yapının mimari özelliklerinden yola çıkılarak burasının gökbilimi üzerine eğitim veren bir medrese olduğu hatta Anadolu'nun ilk rasathanesi olduğu söylenmektedir (Tarım, 1938). Fakat Unat (2011), çalışmasında belirttiğine göre rasathane olarak kullanıldığına dair herhangi bir belgeye ulaşılamamıştır. Üstelik Sayılı ve Ruben'in 1947 yılında yayımlanan Belleten isimli dergide yer alan çalışmasına göre medrese içerisinde bulunan kuyunun derinliği ve çapı rasathane olması için yeterli değildir (Sayıl1, Ruben, 1947). Halen günümüzde bu konu bir gizem olsa da Cacabey Medresesi döneminin mimari özelliklerini çok iyi yansıtan ve uzun yıllar dayanabilen bir eser olmuştur.

Medrese, inşa edildiği yıllardan bu yana birçok yenileme ve güçlendirme çalışması görmüştür. $\mathrm{Bu}$ durum yapının uzun yıllar dayanabilmesini sağlamıştır. Bunun yanında yapının Anadolu Selçuklu döneminden itibaren ayakta kalabilmiş olması sağlam bir strüktüre sahip olmasına ve yeniden işlevlendirilme ile atıl duruma bırakılmamış olmasına bağlıdır.

Çalışma özelinde baktı̆̆ımızda Cacabey Medresesi'nin yeniden işlevlendirilme konusu ele alınmıştır. Cacebey Medresesi (Fotoğraf 7 ve 8), bulunduğu şehre simgesel bir anlam katan tarihi bir değerdir. Şehrin meydanında bulunan eser, şehri tanımlayan, çevresindeki oluşumlara yön veren bir yap1 niteliğindedir. Yapıldığı dönem itibariyle medrese işlevi gören bir eğitim yeridir. Cumhurbaşkanlığı Devlet Arşivleri'nden edinilen bilgiler ışığında 19.yy. sonlarına doğru bu işlevini kaybetmeye başladığı düşünülmektedir. Bu yıllardan itibaren yapı artık cami işlevinde kullanılmaya başlamıştır ve günümüzde bu işlevini devam ettirmektedir.

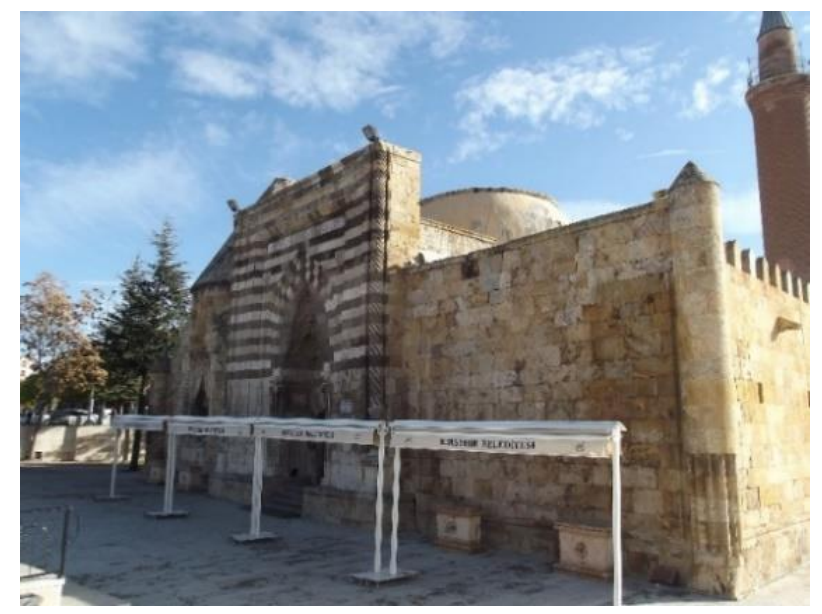

Fotoğraf 7. Cacabey Medresesi Dış Mekân 


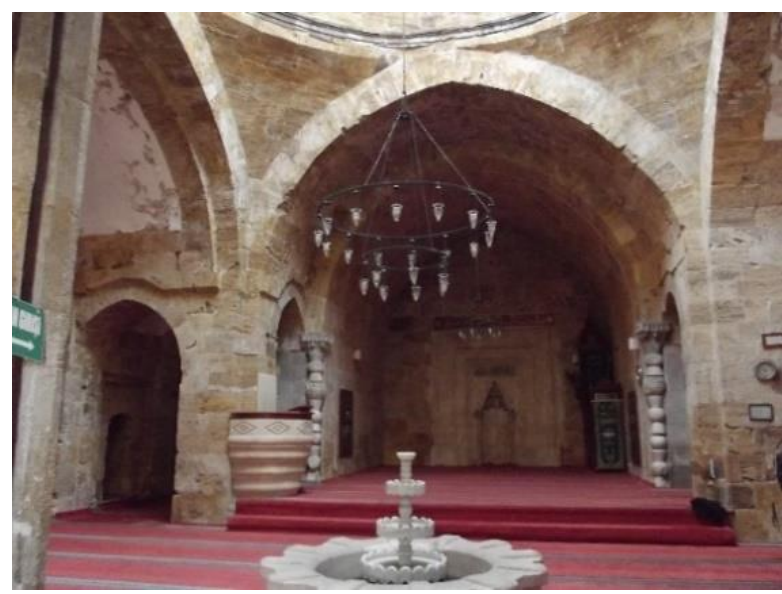

Fotoğraf 8. Cacabey Medresesi İç Mekân

\section{Yapının Geçirdiği Onarımlar ve Kazandığı İşlevler}

Cacabey Medresesi, yıllar içerisinde bir takım onarım ve güçlendirme çalışmalarına maruz kalmış bunun yanında farklı işlevlere de ev sahipliği yapmıştır. Osmanlı Devlet Arşivleri'nden edinilen belgelerde medreseye yapılan müderris tayinlerinden bahsedilmektedir. Buradan yapının halen özgün işlevinde kullanıldığı anlaşılmaktadır.

Bakkal (2011), hazırladığı "İslam Tarihinde Rasathaneler ve Cacabey Medresesi" adlı çalışmasında 1858 yılında Kırşehir'den geçen A. D. Mordtmann isimli gezginin günlüklerinde medresenin mühimmat ambarı olarak kullanıldığını ve harap bir halde olduğunu ifade ettiğini belirtmektedir. Ayrıca Mordtmann yapının yanında bir cami bulunduğunu ve minarenin bu camiye ait olduğunu söylemektedir. Fakat günümüzde camiye ait herhangi bir veriye ulaşılamamıştır. Yapının özgün işlevini yerine getiremez bir halde olduğu da bu yazılarda görülmektedir. Zira bu yıllardan itibaren arşivlerde de müderris tayinleri ile ilgili bir belge bulunmamaktadır. Bulunan tek belge 1868 yılına ait olan "Caca Bey Medresesi Vakfi Müderris Cihetinin Ferağ ve Tevcihi” isimli belgedir.

Osmanlı Devlet Arşivleri'nde bulunan 1899 yılına ait 'Kırşehir'de Caca Cami-i Şerifi'nin Tamiri" isimli resmî belge ile yapının onarımı istenmektedir. Belge üzerinde belirtildiği üzere de artık yapının cami işlevinde kullanıldığı ve bu onarım ile değişikliğin başladığı düşünülmektedir. Hatta işlev değişikliğinden kaynaklı olarak yapıya eklenen müezzin mahfili, vaaz kürsüsü ve minber elemanının bu dönemde eklendiği varsayılmaktadır.

1938 y1lında merkez üssü Kırşehir'e bağlı Akpınar ilçesi olan 6.7 büyüklüğünde bir deprem yaşanmıştır. Bu deprem birçok can kaybına neden olurken çoğu binanın da hasar görmesine veya y1kılmasına sebebiyet vermiştir. Cacabey camisi de hasar gören yapılar içerisindedir. 1942 y1lına ait "Kırşehir'de Türk Eserleri” isimli çalışmasında Ülgen (1942), yapının harap halde olduğunu çalışmasında kullandığı fotoğraflar ile gözler önüne sermektedir. İnan Ocak ve Tanyeli (2016), çalışmasında 1945 yılında yapıya acil müdahale edilmesi gerektiğinin Genel Sekreterlik aracılığıyla Vakıflar Genel Müdürlüğü’ne iletildiğini fakat olumsuz bir cevap aldıklarını belirtmiştir.

1947 yılına gelindiğinde Aydın Sayılı ve Walter Ruben yapıda bulunduğu fakat toprak ile kapalı olduğu söylenen bir rasat kuyusunun izine ulaşmak için çalışma başlatmışlardır (Fotoğraf 5). Bu çalışmalarını Türk Tarih Kurumu'na ait Belleten dergisinde yayımlamışlardır. Çalışma, sadece kuyunun tespitine yönelik yapıldığından yapıda herhangi bir onarıma ya da değişikliğe gidilmemiştir. Hatta bir kuyunun var olduğu keşfedildikten sonra kuyu tekrar kapatılarak eski haline getirilmiştir (Sayılı ve Ruben, 1947). 


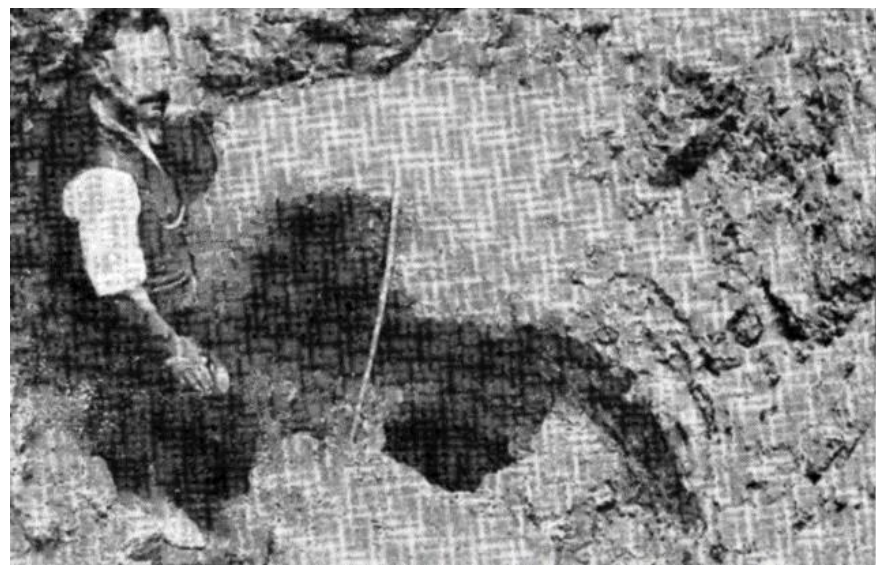

Fotoğraf 5. Kuyuyu Tespit Etmek İçin Yapılan Çalışma (Sayılı ve Ruben, 1947)

Cumhurbaşkanlığı Devlet Arşivleri’nden edinilen 1948 yılına ait bir rapor, yapının restorasyonu için girişimlerde bulunulduğunu ve bu konuda detaylı bir çalışma yapıldığını söylemektedir. Valilik'ten Vakıflar Genel Müdürlüğü’ne gönderilen yazıda, yıllardır onarım görmeyen yapının harap halde olduğu, kubbesinde bulunan açıklıklardan kaynaklı içeriye su sızdığı ve kubbenin her an göçebilecek derecede tehlike arz ettiği belirtilmektedir. Ayrıca caminin kubbesine yönelik bir takım onarım çalışmalarından bahsetmekte fakat bu çalışmaların yeterli olmadığını esaslı bir tamir görmesi gerektiğinin altını çizmektedir.

İnan Ocak ve Tanyeli (2016), hazırladıkları çalışmada belirttikleri üzere valiliğin tamir isteği 1951 yılında karşılık bulmuştur. Gönderilen şartnamede belirtildiğine göre yapıda bulunan aydınlık feneri yıkılacak ve yerine yeni bir fener yapılacaktır. Yapının güneydoğu köșesinde bulunan minareye alem ve petek yapılacak ve yapının deforme olan kısımları taş kaplanacaktır. Hazırlanan bu şartname Ali Saim Ülgen öncülüğünde bir ekiple 1959 yılında uygulamaya geçirilmiştir. Şartname de yer alan maddelerin çoğu gerçekleştirilirken, kubbe üzerinde bulunan aydınlık feneri yıkılmış fakat yerine yenisi yapılmayarak kubbenin açık kalan tepesi bir camekan ile örtülmüştür (Fotoğraf 6 ve 7). Yapının birçok yerinde çimento harç kullanılmıştır. Yapılan onarımlar ile ilgili Cumhurbaşkanlığı Devlet Arşivi'nde 1960 yılına ait bir kararname de yer almaktadır. Yapılan çalı̧̧maların kapsamlı olmasından kaynaklı olarak yapı uzun bir süre onarıma ihtiyaç duymamıştır.

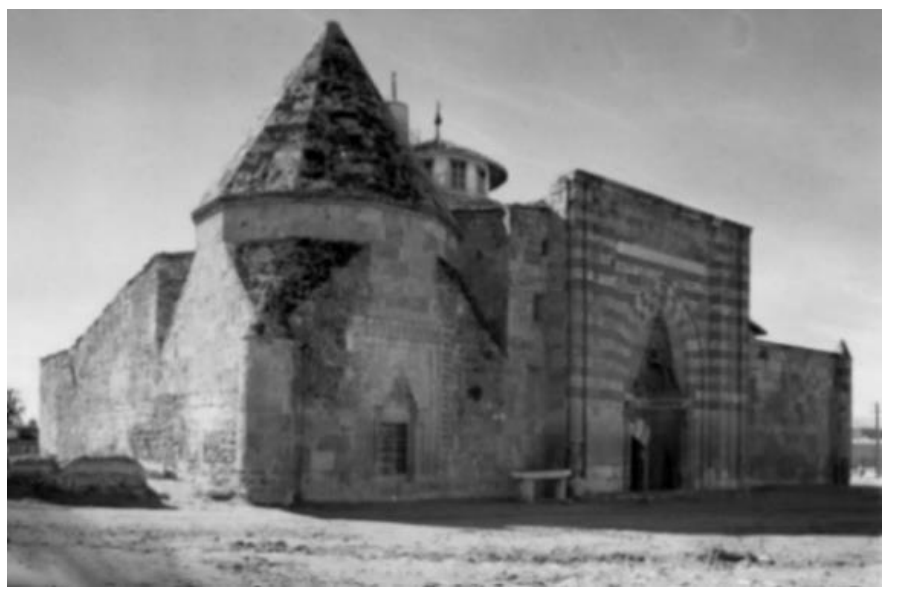

Fotoğraf 6. 1940’larda Cacabey Medresesi (Vakıflar Genel Müdürlüğü Arşivi, 2005) 


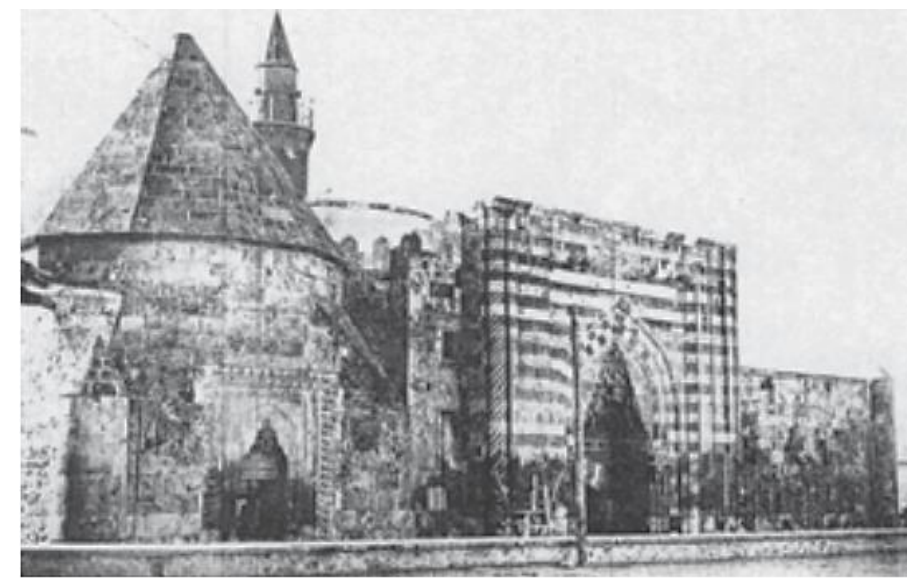

Fotoğraf 7. 1950’lerde Geçirdiği Büyük Onarım Sonrası Cacabey Medresesi (Şimşek, 2006)

1947 yılında varlı̆̆ 1 tespit edilen ancak üzeri tekrar kapatılan kuyu 1996 yılına gelindiğinde Balibeyoğlu'nun (1998) da çalışmasından anlaşılacağı üzere Kırşehir Belediyesi tarafindan gerçekleştirilen çalışma neticesinde tekrar açtırılmıştır. Bunun haricinde başka bir değişiklik yapılmamıştır.

Yapıda meydana gelen drenaj problemleri 2005 yılında yapının restorasyon görmesine zemin hazırlamıştır. Kayseri vakıflar genel müdürlüğünden edinilen bilgilere göre yapıdaki drenaj problemi 2006 yılında uygulamaya geçen restorasyon çalışmaları ile büyük oranda halledilmiştir. Ayıca kubbesi üzerinde bulunan piramidal örtü değiştirilmiş yerine küre parçası biçiminde bir cam eleman kullanılmıştır. Yapıda havalandırmanın yetersiz olmasından kaynaklı meydana gelen nem problemi yeni bir çalışma yapılması doğrultusunda Kayseri Vakıflar Genel Müdürlüğü’nü hareket geçirmiştir. Fakat sunulan önerilerin hiçbiri kesin bir çözüm sağlamadığından bu çalışma sonuçsuz kalmıştır.

İlerleyen yıllarda rutubet probleminin daha fazla sorun teşkil etmeye ve üst örtüsünün su sızdırmaya başlaması 2019 yılında yeni bir restorasyon çalışmasının başlamasına neden olmuştur. Elde edilen bilgilere göre yapının ana kubbesinde yer alan cam eleman değiştirilecek ve eski yalıtım malzemesi yenilenecektir. Ancak 2020 yılının başlarında patlak veren virüs salgını restorasyon çalışmalarının yavaşlamasına neden olmuştur. Günümüzde yenileme çalışmaları halen devam etmektedir.

\section{Yeniden İşlevlendirme Kapsamında Yapılan Müdahaleler}

Cacabey Medresesi yeniden işlevlendirme süreci sonrasında ihtiyaç gereği birtakım müdahaleler geçirmiştir. Bu müdahaleler; mimari öğelerde, strüktür sisteminde, tesisat ve aydınlatmada, donat1 elemanlarında ve çevre düzenlemesinde kendini göstermektedir. Yapılan inceleme neticesinde yapıda meydana gelen değişiklikler tespit edilmiş bu değişikliklerden başlıklar halinde bahsedilmiştir.

\section{Planlamadaki Müdahaleler}

Yapının kazandığı cami işlevi sonrasında değişen ihtiyaçlara göre kullanım alanlarında birtakım zorunlu değişiklikler yaşanmıştır. Bu değişiklikler plan üzerinde mahal numarası verilerek açıklanmıştır (Şekil 3). 


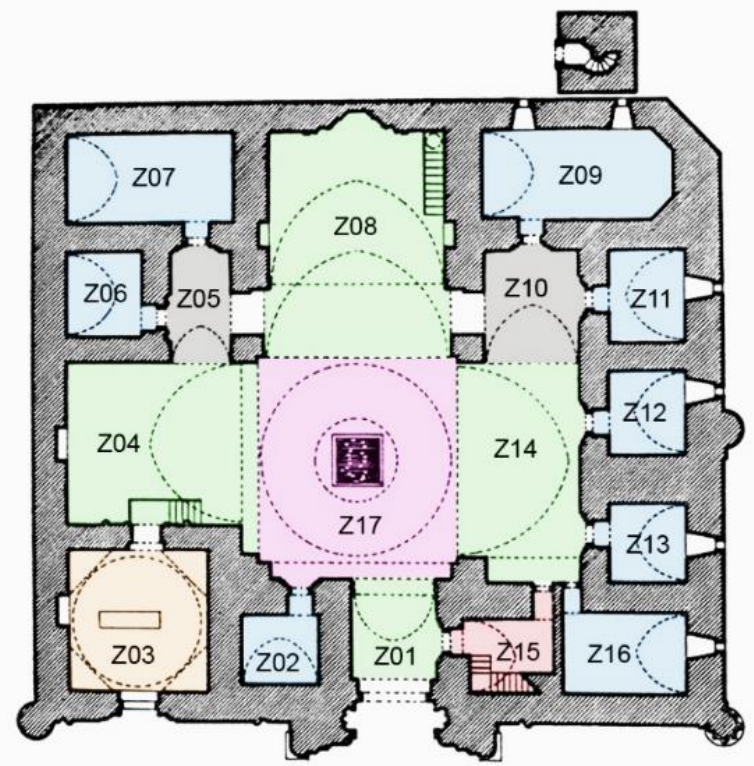

Şekil 3. Cacabey Medresesi Planı (Ülgen, 1942)

Yapıya girişte sağ ve sol tarafta yer alan Z02 ve Z16 bölümleri medrese öğrencilerine ait birer hücre işlevinde iken günümüzde kadınlar için ibadet mekânı olarak planlanmıştır. Bu hücrelere işlev değişikliği dışında özgün halini değiştirecek bir müdahale yapılmamıştır. Yapının Z08 bölümü ana eyvanın yer aldığı bölümdür. Z04 ve Z14 eyvanları gibi eğitim verilen mekanlardan biridir. Günümüzde bu alanlar ibadet amaçlı kullanılmaktadır. Bununla birlikte medresenin avlusu (Z17) da ibadet alanına katılmıştır. Yapının Z13 bölümü, kullanımının medrese öğrencilerine ait olduğu hücrelerden biri iken günümüzde bu bölüm camiye ait kitap ve dokümanların bulunduğu kütüphane işlevindedir. Yapının güneydoğu köşesinde bulunan minare elemanının ise medreseye ait bir gözlem kulesi oluğu ya da zamanlar yapının yanında bulunan mescit birimine ait olan bir minare elemanı olduğu gibi görüşler mevcuttur. Yeni işlevinin de gerektirdiği sonuç itibariyle günümüzde camiye hizmet veren minare işlevindedir.

\section{Strüktürel Sisteme Yönelik Müdahaleler}

Yeniden işlevlendirme çalışmaları sonrasında, yapının; mevcut strüktürel sistemine büyük bir eklentinin olmadığı yalnızca hasar gören cephe taşlarının değiştirildiği ya da kaplandığı görülmektedir. Bununla birlikte kubbenin tepesinde yer alan açıklığın cam eleman kullanılarak örtüldüğü ve merkezî holün ortasında bulunan kuyu elemanın ise doldurulduğu gözlemlenmektedir. Ayrıca yapı zemini ahşap döşeme ile kapatılmıştır (Ünsal, Karaköse, Tuğluca, Özüçetin, 2013).

Tesisat ve Aydınlatmaya Yönelik Müdahaleler

Cacabey Medresesi'nin aydınlatmasında, doğal ve yapay 1şıktan yararlanılmıştır. Kazandığı yeni işlev sonrasında yapıda yapay aydınlatma elemanı olarak sarkıt aydınlatma elemanları kullanılmıştır. Cacabey Medresesi'nin yeniden işlevlendirilmesi ile gerekli olan müdahalelerden biride 1sıtmadır. Bu amaçla caminin 1sınmasını sağlamak için zemine 1sıtma sistemleri döşenmiş̧tir. Ayrıca gerekli makine ve tesisat elemanları da Z07 mahal adına sahip hücre içerisine yerleştirilmiştir.

\section{İlave Edilen Donatı Elemanları}

Cacabey Medresesi, cami olarak yeniden işlevlendirilirken, yapıya; ayakkabılık, müezzin mahfili, minber, vaaz kürsüsü gibi donatı elemanları eklenmiştir. Yapıya girişte sağ tarafta yer alan Z15 bölümü, üst kata ulaşılmasını sağlayan merdivenin bulunduğu bölümdür. Günümüzde bu bölüme eklenen ahşap raflar ile caminin ayakkabılığı olarak da kullanılmaktadır. Z04 ve Z14 bölümlerine yeni 
işlev dahilinde kagir yapıda bir müezzinlik eklenmiştir. Yapının ana eyvanının (Z08) ise orijinal işlevinden kaynaklı olarak özgün bir mihrabı vardır. Fakat mihrabın sağ tarafında bulunan ahşap minber ve eyvanın sol alt köşesinde bulunan kagir yapıdaki vaaz kürsüsü sonradan eklenmiştir.

\section{Yakın Çevreye Yapılan Müdahaleler}

Yapının yeniden işlevlendirilmesi ile yakın çevresinin kullanıcıların kullanımına yönelik yeniden düzenlenmesi gerekli bir müdahaledir. Bu amaçla yapının yakın çevresi birçok kez peyzaj çalışmalarına konu olmuştur. Bununla birlikte yapının etrafında yükselen toprak kotu yapının girişi ile eş seviyeye getirilmiş ve kullanıcıların ulaşabilirliği açısından kolaylık sağlanmıştır.

\section{Yeni İşlevin Sosyo-Kültürel, Ekonomik ve Fiziksel Yönden Değerlendirilmesi}

Yeniden işlevlendirilen yapılara yaşamlarını sürdürmelerine imkân sağlayacak, bununla beraber yapının orijinal haline zarar vermeyecek bir işlev tanımlanmalıdır. Seçilen yeni işlevde yapının fiziksel özelliklerinin korunmasına dikkat edildiği kadar sosyal ve kültürel açıdan anlamının korunması da gözetilmelidir. Ayrıca ekonomik açıdan bakıldığında da yeni işlev, yapıya, bulunduğu bölgeye ve kültürel turizme katkı sağlamalıdır (Worthing ve Bond, 2008). Tanımlanan yeni işlevin kullanımında sosyal, çevresel ve kültürel faktörler, tarihi yapının fiziksel özellikleri ve alanyazında yer alan tüm ulusal ve uluslararası restorasyon ilkeleri ölçüt alınmaktadır (Özkan Yazgan, 2011). Cacabey Medresesi de kazandığı yeni işlev kapsamında bu ölçütler baz alınarak değerlendirilmiş ve bu yönler üç farklı kategoride sunulmuştur. Tablo 1'de gösterildiği gibi sosya-kültürel, ekonomik ve fiziksel açıdan incelenen yapının kullanıcı ve çevre ile uyumu değerlendirilmiştir. Ayrıca kazandığı yeni işlevin yapının özgün nitelikleri ile bir harmoni içerisinde olup olmadığı yorumlanmıştır.

Tablo 1

Cacabey Medresesi'nin Uyarlanabilir Yeniden Kullanımındaki Yönleri

\begin{tabular}{lll}
\hline Sosyo-Kültürel Yönler & Ekonomik Yönler & Fiziksel Yönler \\
\hline $\begin{array}{l}\text { Yeniden işlevlendirildikten } \\
\text { sonra kullanıcılar tarafından } \\
\text { orijinal işlevi farkedilmektedir }\end{array}$ & $\begin{array}{l}\text { Kullanıcılar için yeni fonksiyon } \\
\text { ekonomik yararlar sağlamaktadır. }\end{array}$ & $\begin{array}{l}\text { Farklı işleve sahip yapılar ile } \\
\text { uyum içerisindedir. }\end{array}$ \\
\hline $\begin{array}{l}\text { Yeniden işlevlendirildikten } \\
\text { sonra yerel halk tarafından } \\
\text { orijinal işlevi farkedilmektedir }\end{array}$ & $\begin{array}{l}\text { Yeni işlevi ile kar sağlama } \\
\text { potansiyeline sahiptir. }\end{array}$ & Diş çevre ile uyum içerisindedir. \\
\hline $\begin{array}{l}\text { Bulunduğu bölge için simgesel } \\
\text { özellik taşımaktadır. }\end{array}$ & $\begin{array}{l}\text { Bölgedeki mülk değerini } \\
\text { artırmaktadır. }\end{array}$ & $\begin{array}{l}\text { Orijinal işlevi ile yeni işlevi uyum } \\
\text { içerisindedir. }\end{array}$ \\
\hline $\begin{array}{l}\text { Bölgenin tanıtımına katkı } \\
\text { sağlamaktadır. }\end{array}$ & $\begin{array}{l}\text { Kültürel turizme katkı } \\
\text { sağlamaktadır. }\end{array}$ & Görsel kirliliği önlemektedir. \\
\hline
\end{tabular}

Bölgenin ihtiyaçlarını karşılamaktadır.

Restorasyon çalışmaları başarılı bir şekilde tamamlanmıştır.

Kullanıcılar için yeni fonksiyon sosyal yararlar sağlamaktadır.

\begin{tabular}{l} 
Kullanıcılar için yeni fonksiyon \\
kültürel yararlar sağlamaktadır. \\
\hline Kullanıcılar için yaşam \\
koşullarının kalitesini \\
artırmaktadır. \\
\hline
\end{tabular}

Kullanılan malzemeler ve yapılan eklemeler yapının orijinali ile uyumludur.

Engelli kullanıcılar için yapı ulaşılabilir değildir.

Kullanıcılar için yaşam artırmaktadır.

Yayalar ve araçlar için yapı
ulaşılabilir durumdadır.

Tarihi yapının havalandırma ve doğal aydınlatması fiziksel açıdan yeni işlev için yeterli değildir. katkı sağlamaktadır.

Tablo Misırlısoy, D. ve Günçe, K. (2016). A critical look to the adaptive reuse of traditional urban houses in the Walled City of Nicosia. Journal of Architectural Conservation, 22(2), 149-166. 10.1080/13556207.2016.1248095 künyeli çalışmadan uyarlamadir. 


\section{Tarihi Cacabey Medresesi’nin Sosya-Kültürel Yönden Değerlendirilmesi}

Cacabey Medresesi bulunduğu şehir için simge niteliği taşımaktadır. Kazandığı cami işlevi bu özelliğini kaybettirmemiş aksine yapıyı daha güçlü bir konuma getirmiştir. Medresenin yeni işlevi kullanıcılar tarafindan benimsenmiş, sosyal ve kültürel açıdan kullanıcılara yarar sağlamıştır. Yapı kazandığı yeni işlev ile bölgenin ihtiyaçlarını karşılar düzeye gelmiş ve ortak bir kullanım alanı oluşturmuştur. Ayrıca Cacabey Medresesi, yeni bir işlev kazanmış olmasına rağmen yapının orijinal hali hem yapıyı çok iyi bilen bölge halkı hem de diğer kullanıcılar tarafından fark edilecek düzeydedir. Eski işlevinin izlerini taşımaktadır.

\section{Tarihi Cacabey Medresesi’nin Ekonomik Yönden Değerlendirilmesi}

Cacabey Medresesi sahip olduğu tarihi kimliği ve mimari özellikleri sayesinde her yıl birçok turist grubuna ev sahipliği yapmakta ve bu sayede kültürel turizme katkı sağlamaktadır. Bunun yanında sahip olduğu yeni işlev ile bulunduğu bölgenin mülk değerlerini artırmakta ve yerel halka ekonomik açıdan kar sağlama potansiyeli kazandırmaktadır.

\section{Tarihi Cacabey Medresesi’nin Fiziksel Yönden Değerlendirilmesi}

Cacabey Medresesi'nin kazandığı cami işlevi yapının orijinal hali ile uyum içerisindedir. Yeni işlev ile yapılması gereken birtakım zorunlu değişiklikler yapıya zarar verecek düzeyde değildir. Yapılan eklemeler ve kullanılan malzemeler geri alınabilir özelliktedir. Bu durum yapının özgün haline dönüşü olmayan hatalar yapılmasına engel olmaktadır. Bununla birlikte yapı, içinde bulunduğu konum itibari ile çevresine uyum sağlamış durumdadır. Yeni işlevden kaynaklı olarak şehir siluetine zarar verilecek bir işleme maruz kalmamış görsel açıdan bir kirlilik oluşturmamıştır. Yapı ulaşılabilirlik açısından incelendiğinde yayalar ve araçlar için ulaşılabilir olmasına karşın engelli kullanıcılar için sorun teşkil etmektedir. Kazandığı yeni işlev bu durumu değiştirmemiştir. Fiziksel açıdan genel olarak bakıldığında; yapının orijinal kimliğine ve yapı malzemelerine saygı gösterilmiştir.

\section{Sonuç, Tartışma ve Öneriler}

Tarihi yapılara yeni işlevler kazandırarak sürdürülebilirliklerini sağlamak restorasyon ve koruma çalışmaları kadar önemli bir yere sahiptir. Eski işlevlerini kaybeden yapıların sadece koruma ile gelecek nesillere aktarılması güçtür. Onları yeniden toplumun ihtiyaçlarına sunmak, yeniden kullanılır hale getirmek gerekmektedir. Zira kullanılmayan yapılar bir süre sonra atıl duruma gelecektir. Çağdaş koruma tekniklerinden biri olan yeniden işlevlendirme bu durumu ortadan kaldırmaya yöneliktir.

Kırşehir ili Merkez ilçesinde bulunan Cacabey Medresesi; artan nüfus oranı, değişen kültürel değerler ve gelişen teknoloji gibi sebeplerle eski işlevini yitirmiş ve kendisine tanımlanan cami işlevi ile tekrar kullanıma açılmıştır. Medrese, kazandığ 1 yeni işlevin mekânsal gerekliliklerini karşılarken aynı zamanda kullanıcıların ihtiyaçlarına yönelik olarak kullanım sağlamaktadır. Yapı; mimari özgünlüğünü, eski kimliğini kaybetmemiş aynı zamanda ibadethane işlevi ile bir cami olarak kullanılabilmiştir. $\mathrm{Bu}$ durumun sonucu olarak uzun yıllar korunmuş, topluma hizmet etmeye devam etmiştir. Bölgeye kültürel turizm açısından önemli katkılar sağlamış ve mimarisi ile ilham kaynağı olmuştur. Yeniden işlevlendirme ile yok olması engellenen yapı, şehrin simgesi ve turistlerin ilgi odağ haline gelmiş, ekonomik olarak şehri kalkındırmıştır.

Yapılan bu çalışma ile Cacabey Medresesi'nin önemi hem Kırşehir halkının hem de gelen yerli ve yabancı turistlerin gözünde daha iyi anlaşılacaktır. Değerinin daha iyi anlaşılması ise onu korumak için göstereceğimiz gayretin seviyesini artıracak, böylece yaşam ömrü uzatılan yapı, gelecek nesillere yaşayan bir hazine olarak aktarılabilecektir. Ayrıca bu makale ışığında, işlevini kaybetmiş ve kullanıma kapatılmış birçok medresenin yeniden işlevlendirilmesinin gerekliliği ve önemi daha iyi anlaşılacaktır. 


\section{Yazarların Katkı Oranı}

Bu makaleye birinci yazarın $\% 60$, ikinci yazarın $\% 40$ oranında katkısı vardır.

\section{Çıkar Çatışması}

Çıkar çatışması teşkil edebilecek bir durum yoktur.

Açıklama: Bu makale, Gazi Üniversitesi Fen Bilimleri Enstitüsü Mimarlık Anabilim Dalında hazırlanan "Tarihi Cacabey medresesinin yapısal davranışının incelenmesi” isimli yüksek lisans tezinden türetilmiştir

\section{Kaynaklar}

Ahunbay, Z. (1988). Mimarbaşı Kocasinan, yaşadığı çă̆ ve eserleri. S. Bayram (Ed.). Mimar Sinan'ın eğitim yapıları içinde (ss. 239-309). İstanbul: Vakıflar Genel Müdürlüğü Yayınları.

Aydın, A. ve Şahin, Ö. (2018). Tarihi yapıların yeniden işlevlendirilmesi: Isparta Aya İshotya (Yorgi) Kilisesi’nin Gül Müzesi'ne dönüşümü. Türkiye Bilimler Akademisi Kültür Envanteri Dergisi, $17,63-75$.

Bakkal, A. (2011, 15-17 Ekim). İslâm Tarihinde Rasathaneler ve Caca Bey Medresesi. E. Güleç, M. F. Köksal, S. N. Işı1ksalan, A. Gündüz (Ed.), Kırş̧ehir Ahi Evran Üniversitesi. 1.Uluslararası ahilik kültürü ve Kırşehir sempozyumu içinde (ss.1291-1323). Kırşehir: Ahi Evran Üniversitesi Ahilik Kültürünü Araştırma ve Uygulama Merkezi.

Balibeyoğlu, L. (1998). 13.yüzyılda Kırşehir Nureddin Cacabey ve Ahmet Gülşehri. Hacı Bektaş Veli Araştırma Dergisi, 6, 115-122.

Başbakanlık Özel Kalem Müdürlüğü. (1947). Kırșehir'in çeșitli ihtiyaçları ile Cacabey Medresesi'nin tarihi önemi ve restorasyonu hakkında, T.T.K tarafindan hazırlanan rapor. No.117, Gömlek No. 737-2. http://www.devletarsivleri.gov.tr/ adresinden 14.04.2020 tarihinde erişilmiştir.

Kararlar Daire Başkanlığı. (1960). Kırşehir'de bulunan Cacabey Camii onarımına ait ihalenin kabulü. No. 156, Gömlek No. 14. http://www.devletarsivleri.gov.tr/ adresinden 14.04.2020 tarihinde erişilmiştir.

Başbakanlık Osmanlı Arşivi. (1757). Kırşehri'ndeki Caca Bey Medresesi müderrislerine yeniden berat verilmesi. No. 61, Gömlek No.3046. C..MF.. http://www.devletarsivleri.gov.tr/ adresinden 14.04.2020 tarihinde erişilmiştir.

Başbakanlık Osmanlı Arşivi. (1767). Kırşsehir'in Medrese mahallesindeki Caca Bey Medresesi'ne müderris tayini. No. 146, Gömlek No.7281. C..MF.. http://www.devletarsivleri.gov.tr/ adresinden 14.04.2020 tarihinde erişilmiştir.

Başbakanlık Osmanlı Arşivi. (1868). Kırşehir kazasında kain Caca Bey Medresesi vakfı müderris cihetinin ferağ ve tevcihi. No. 37, Gömlek No.1833. C..MF.. http://www.devletarsivleri.gov.tr/ adresinden 14.04.2020 tarihinde erişilmiştir.

Başbakanlık Osmanlı Arşivi. (1899). Kırşehir'de Caca Cami-i Şerifi'nin tamiri. No. 1379, Gömlek No. 103409. BEO. http://www.devletarsivleri.gov.tr/ adresinden 14.04.2020 tarihinde erişilmiştir.

Demiralp, Y. (2006). Osmanlı öncesi Anadolu medreselerinde örtü ve erken Osmanlı medreseleriyle karşılaştırma. Sanat Tarihi Dergisi, 15(2), 29-48. 
Ocak, Z. ve Tanyeli, G. (2016). Kırşehir Cacabey Medresesi ve onarımları. Türk-İslam Medeniyeti Akademik Araştırmalar Dergisi, 11 (21), 145-170.

İslamoğlu, Ö. (2018). Tarihi yapıların yeniden kullanılmasında yapı-işlev uyumu: Rize Müzesi örneği. Journal of History Culture and Art Research, 7(5), 510-523.

Karapınar, M. (1997). Çevre ve ihtiyaç programı verilerinin mimari tasarıma etkisi üzerine bir değerlendirme. Yüksek Lisans Tezi, İstanbul Teknik Üniversitesi, Fen Bilimleri Enstitüsü, İstanbul.

Karasar, N. (2007). Bilimsel araştırma yöntemi. Ankara: Nobel.

Kaya, A. (2018). Anadolu Selçuklu medreseleri ve bugünkü durumlarının tespiti (başlangıcından 1243 yllına kadar). Yüksek Lisans Tezi, Mimar Sinan Güzel Sanatlar Üniversitesi, Sosyal Bilimler Enstitüsü, İstanbul.

Kayseri Vakıflar Genel Müdürlüğü Arşivi. (2005). Kırşehir Cacabey Medresesi Restorasyon ve Çevre Düzenleme Projesi Raporu, Kayseri.

Kincaid, D. (2002). Adapting buildings for changing uses. London: Routledge.

Kuran, A. (1969). Anadolu medreseleri. Ankara: Türk Tarih Kurumu.

Misırlısoy, D. ve Günçe, K. (2016). A critical look to the adaptive reuse of traditional urban houses in the Walled City of Nicosia. Journal of Architectural Conservation, 22(2), 149-166.

Önkal, H. (1996). Anadolu Selçuklu türbeleri. Ankara: Türk Tarih Kurumu.

Yazgan, E. (2011). Anıtsal kültür varlıklarının müze olarak kullanımına yönelik yaklaşımın İstanbul İbrahim Paşa sarayı örneğinde irdelenmesi. Doktora Tezi, Gazi Üniversitesi, Fen Bilimleri Enstitüsü, Ankara.

Öztürk, E. ve Esmer, M. (2019). İstanbul'daki 16-18. yüzy1llara ait medreselerin mevcut işlevlerinin koruma amaçlı değerlendirilmesi, Kent Akademisi, 12(3), Pages 561-574

Saraç, Ö. ve Tanrısever, C. (2018). Kastamonu'da yeniden işlevlendirilen tarihi yapıların sürdürülebilirliğe etki eden çekicilik faktörleri. Anatolia: Turizm Araştırmaları Dergisi, 29(2), 151-163.

Sayıl1, A. ve Ruben, W. (1947). Türk Tarih Kurumu adına Kırşehir'de Cacabey Medresesinde yapılan araştırmanın ilk ön raporu. Belleten, 11(44), 671-81.

Şakı, S. (2019). Osmanlı dönemi medrese yapılarının yeniden işlevlendirilmesi: Kepenekçi Sinan Medresesi örneği. Yüksek Lisans Tezi, İstanbul Arel Üniversitesi, Fen Bilimleri Enstitüsü, İstanbul.

Doğan, N. (2019). Anadolu Selçuklu medreseleri ve darüşşifalarında türbe. Belleten, 83(297), 519-554.

Şimşek, A. (2006). Cacabey ve medresesi. Kırşehir: Arter.

Şimşek, M. (2017, 2-4 Kasım). Medreselerin yeniden işlevlendirilmesinde değerlerinin korunması sorunsalı; Hadım Hasan Paşa medresesi ve Esekapı medresesi örnekleri. Uluslararası Katılımlı 6. Tarihi Yapıların Korunması ve Güçlendirilmesi Sempozyumu, Karadeniz Teknik 
Üniversitesi, Trabzon. http://www.imo.org.tr/resimler/ekutuphane/pdf/17933_03_18.pdf adresinden 14.06.2020 tarihinde erişilmiştir.

Tarım, C. H. (1938). Kırşehir tarihi üzerinde araştırmalar I. Kırşehir: Vilayet Matbaası.

Tekin, B. H. (2018). İstanbul'daki Mimar Sinan eseri yeniden işlevlendirilmiş medreselerin yeni işlev gereği değişen mimari özellikleri. El-Cezerî Fen ve Mühendislik Dergisi, 5(2), 331-345.

Unat, Y. (2011, 19-23 Ekim). Selçuklularda Astronomi Bilimi. 2. Uluslararası Selçuklu Sempozyumu, Selçuk Üniversitesi, Konya.

https://www.academia.edu/7453585/Sel\%C3\%A7uklularda_Astronomi_Bilimi adresinden 10.06.2020 tarihinde erişilmiştir.

Ülgen, A. S. (1942). Kırşehir'de Türk eserleri. Vakıflar Dergisi, 2, 254-255.

Ünsal, V., Karaköse, H., Tuğluca M. ve Özüçetin, Y. (2013). Ortaçağda Kırşehir. Y. Özüçetin (Ed.). Kırşehir (siyasi tarihi ve Kırşehir tarihi bibliyografyası) içinde (ss. 91-163). Ankara: Gökçe.

Worthing, D. ve Bond, S. (2008). Managing built heritage: the role of cultural significance. London: Blackwell Publishing.

Venedik Tüzüğü. (1964). Venedik tüzügü̈. http://www.icomos.org.tr/Dosyalar/ICOMOSTR_tr0243603 001536681730.pdf adresinden 10.06.2020 tarihinde erişildi.

Yaldız, E. (2003). Konya'da ki medrese yapılarının yeniden kullanım koşullarına göre değerlendirilmesi. Yüksek Lisans Tezi, Selçuk Üniversitesi, Fen Bilimleri Enstitüsü, Konya. 


\section{Extended Abstract}

\section{Introduction}

Historical buildings that have survived centuries ago are of great value to every society. These structures that help us connect with our past should be able to be transmitted to the future and presented as a document to the next generations. For this purpose, historical buildings have been taken under protection and have undergone necessary restorations or are undergoing. While many historical buildings can continue to function in the past, structures such as madrasahs and caravanserais cannot find a place for themselves today. In order to ensure the continuity of such buildings, it will not be enough to restore and preserve them. In order to prevent historical buildings that have a functional problem today can be brought back to life with a new function and their sustainability can be maintained.

In this study, first of all, information was given about the re-functioning of historical buildings and the points that should be considered in this process were mentioned. Afterwards, the historical buildings were reduced to madrasah specific and within this scope, the function harmony of the mosquemadrasah was evaluated. Examples of the subject selected from the turkey with medreses intended better understanding. In the continuation of the study, the re-functioning of the Cacabey Madrasah, which was determined as the main subject, as a result of changing conditions was discussed. The history, architectural and structural features of the building are mentioned, the functions it has gained over time and the renovation works it has undergone. The harmony of the interventions it was exposed to as a result of the mosque function it acquired with the old identity and original architecture of the building was evaluated in socio-cultural, economic and physical terms.

\section{Method}

Tracing technique, one of the qualitative research methods, was used in the study. In order to obtain data on the field study, a wide-ranging literature review was made and the necessary official sources were obtained from the state archives. measured drawings and restoration projects that have been made so far of the building from Kayseri General Directorate of Foundations, the official correspondence of the structure was obtained from the Republic of Turkey and Chairman of the Presidential State Archives website. Afterwards, the building was examined and photographed on-site, and the changes it underwent through re-functioning were reported. As a result of the data obtained, the repairs and functions that the building has undergone since the years it was built have been revealed. However, changes in the structure; It was determined on the basis of plan, structure and element, and then the harmony of the new function with its original state was evaluated in terms of socio-cultural, economic and physical aspects.

\section{Findings}

Cacabey Madrasah is a historical value that adds a symbolic meaning to the city where it is located. It is an education place that functions as a madrasah as of the time it was built. In the light of the information obtained from the Presidential State Archives, the 19th century. It is thought that it started to lose this function towards the end. Since these years, the building has started to be used as a mosque and today it continues this function.

The Cacabey Madrasah has been evaluated in many ways with its new function and these aspects are presented in three different categories. The harmony of the building, which is evaluated sociallyculturally, economically and physically, with the user and the environment was evaluated. In addition, it was interpreted whether the new function it gained was in harmony with the original features of the building.

Cacabey Madrasah is a symbol for the city where it is located. The mosque function it gained did not lose this feature, on the contrary, it brought the building to a stronger position. The new function 
of the madrasah has been adopted by the users and has benefited the users socially and culturally. With its new function, it has reached the level of meeting the needs of the region and has created a common use area. In addition, although the Cacabey Madrasah has gained a new function, the original state of the building is at a level that can be noticed by both the people of the region who know the building very well and other users. It bears the traces of its former function.

Cacabey Madrasah hosts many tourist groups every year thanks to its historical identity and architectural features, and thus contributes to cultural tourism. In addition, with the new function it has gained, it increases the property values of the region where it is located and has the potential to provide economic profit to the local people.

The mosque function gained by the Cacabey Madrasah is in harmony with the original state of the building. Some necessary changes that need to be made with the new function are not at a level that will harm the structure. The additions made and the materials used are recyclable. This situation prevents making mistakes that cannot be returned to the original state of the building. However, the building has adapted to its surroundings as of its location. Due to the new function, it was not exposed to a process that would harm the city silhouette, and did not create any visual pollution. When the building is examined in terms of accessibility, although it is accessible for pedestrians and vehicles, it poses a problem for disabled users. The new function it gained did not change this situation. From a physical point of view; The original identity and building materials of the building were respected.

\section{Conclusion, Discussion and Recommendations}

Ensuring the sustainability of historical buildings by providing new functions has an important place as restoration and conservation works. It is difficult to pass on buildings that have lost their former functions to future generations only with protection. It is necessary to bring them back to the needs of society, to make them reusable. Because unused buildings will become idle after a while. Refunctioning, which is one of the contemporary conservation techniques, aims to eliminate this situation.

Cacabey Madrasah located in the central district of Kırşehir; Due to the increasing population ratio, changing cultural values and developing technology, it lost its former function and was opened to use again with the mosque function defined for it. Medrese, while meeting the spatial requirements of the new function it has acquired, also provides usage for the needs of the users. Structure; It did not lose its architectural originality and its old identity, and at the same time it could be used as a mosque with the function of a place of worship. As a result of this situation, it has been preserved for many years and continued to serve the society. It has made significant contributions to the region in terms of cultural tourism and has been a source of inspiration with its architecture. The building, which was prevented from being destroyed by re-functioning, became the symbol of the city and the center of attention of tourists, and developed the city economically.

With this study, the importance of Cacabey Madrasah will be better understood in the eyes of both the people of Kırşehir and incoming local and foreign tourists. A better understanding of its value will increase the level of effort we will show to protect it, so that the structure, whose lifespan is extended, can be passed on to future generations as a living treasure. 